\title{
Neuronal regulation of bone marrow stem cell niches [version
}

\section{1; peer review: 3 approved]}

\section{Claire Fielding 1-3, Simón Méndez-Ferrer ${ }^{1-3}$}

\author{
${ }^{1}$ Haematology, University of Cambridge, Cambridge, UK \\ ${ }^{2}$ Wellcome-MRC Cambridge Stem Cell Institute, Cambridge, UK \\ ${ }^{3}$ National Health Service Blood and Transplant, Cambridge, UK
}

\begin{tabular}{l}
\hline V1 First published: 16 Jun 2020, 9(F1000 Faculty Rev):614 \\
https://doi.org/10.12688/f1000research.22554.1 \\
Latest published: 16 Jun 2020, 9(F1000 Faculty Rev):614 \\
https://doi.org/10.12688/f1000research.22554.1 \\
\hline
\end{tabular}

\section{Abstract}

The bone marrow (BM) is the primary site of postnatal hematopoiesis and hematopoietic stem cell (HSC) maintenance. The BM HSC niche is an essential microenvironment which evolves and responds to the physiological demands of HSCs. It is responsible for orchestrating the fate of HSCs and tightly regulates the processes that occur in the BM, including self-renewal, quiescence, engraftment, and lineage differentiation. However, the BM HSC niche is disturbed following hematological stress such as hematological malignancies, ionizing radiation, and chemotherapy, causing the cellular composition to alter and remodeling to occur. Consequently, hematopoietic recovery has been the focus of many recent studies and elucidating these mechanisms has great biological and clinical relevance, namely to exploit these mechanisms as a therapeutic treatment for hematopoietic malignancies and improve regeneration following BM injury. The sympathetic nervous system innervates the BM niche and regulates the migration of HSCs in and out of the BM under steady state. However, recent studies have investigated how sympathetic innervation and signaling are dysregulated under stress and the subsequent effect they have on hematopoiesis. Here, we provide an overview of distinct BM niches and how they contribute to HSC regulatory processes with a particular focus on neuronal regulation of HSCs under steady state and stress hematopoiesis.

\section{Keywords}

hematopoietic stem cell, niche, autonomic nervous system, adrenergic, cholinergic

\section{Open Peer Review \\ Approval Status \\ 12 \\ 2 \\ 3 \\ version 1 \\ 16 Jun 2020 \\ Faculty Reviews are review articles written by the prestigious Members of Faculty Opinions. The articles are commissioned and peer reviewed before publication to ensure that the final, published version is comprehensive and accessible. The reviewers who approved the final version are listed with their names and affiliations.}

1. Toshio Suda, National University of Singapore, Singapore, Singapore Kumamoto University, Kumamoto City, Japan

2. Partha Dutta, Vascular Medicine Institute, Pittsburgh, USA

University of Pittsburgh Medical Center, Pittsburgh, USA

3. Satoshi Yamazaki, The University of Tokyo, Tokyo, Japan

Any comments on the article can be found at the end of the article. 
Corresponding author: Simón Méndez-Ferrer (sm2116@cam.ac.uk)

Author roles: Fielding C: Writing - Original Draft Preparation; Méndez-Ferrer S: Conceptualization, Resources, Supervision, Writing Original Draft Preparation, Writing - Review \& Editing

Competing interests: No competing interests were disclosed.

Grant information: Original work discussed in this article was supported by core support grants from the Wellcome Trust (203151/Z/16/Z) and the Medical Research Council (MRC) to the Cambridge Stem Cell Institute, National Health Institute Blood and Transplant (United Kingdom), Horizon2020 grant ERC-2014-CoG-648765, and a Cancer Research UK Programme Foundation Award (C61367/A26670).

The funders had no role in study design, data collection and analysis, decision to publish, or preparation of the manuscript.

Copyright: ( 2020 Fielding C and Méndez-Ferrer S. This is an open access article distributed under the terms of the Creative Commons Attribution License, which permits unrestricted use, distribution, and reproduction in any medium, provided the original work is properly cited.

How to cite this article: Fielding $C$ and Méndez-Ferrer $\mathrm{S}$. Neuronal regulation of bone marrow stem cell niches [version 1; peer review: 3 approved] F1000Research 2020, 9(F1000 Faculty Rev):614 https://doi.org/10.12688/f1000research.22554.1

First published: 16 Jun 2020, 9(F1000 Faculty Rev):614 https://doi.org/10.12688/f1000research.22554.1 


\section{Structural components of the bone marrow niche}

The bone marrow (BM) is highly vascularized to provide nutrients and oxygen. The nutrient artery and vein infiltrate the compact bone and subsequently branch to form small arterioles. These arterioles connect via transition zone vessels (also called type $\mathrm{H}$ capillaries) to the venous sinusoids near the endosteum, which is the interface between the bone surface and the $\mathrm{BM}^{1-3}$. BM sinusoids form a complex network and are found in the central marrow, operating as the site where hematopoietic cells migrate in and out of the $\mathrm{BM}^{4}$, although a recent study suggested that transcortical vessels in bone represent an additional important migration route ${ }^{5}$.

Each niche likely operates different functions and exhibits its own cellular composition. Key cellular niche components are the stromal cells necessary for producing niche factors that directly act on hematopoietic stem cells (HSCs). Perivascular cells identified by the expression of the intermediate filament protein NESTIN contain BM mesenchymal stem cells (MSCs) and can be divided in Nestin-Gfp transgenic mice into two subsets according to their GFP expression: Nes-GFP ${ }^{\text {bright }}$ and Nes-GFP ${ }^{\mathrm{dim}}$. Nes-GFP ${ }^{\mathrm{dim}}$ cells are located around the sinusoids, and Nes-GFP ${ }^{\text {bright }}$ cells are located around the arterioles ${ }^{2}$ and the transition zone vessels ${ }^{6}$. Stromal cells can be further divided to neuron-glial antigen (NG2)-expressing cells ${ }^{2}$, Cxcl12-abundant reticular (CAR) cells ${ }^{7}$, and cells expressing leptin receptor $(\mathrm{LepR})^{1}$, all of which overlap with $\mathrm{Nes}^{-\mathrm{GFP}^{+}}$cells to varying degrees ${ }^{8,9}$.

$\mathrm{NG}^{+}$cells ensheath the arterioles which have been proposed as an important niche for regulating the quiescence of HSCs via the secretion of Cxcl12, whereas others have attributed the same function to $\mathrm{LEPR}^{+}$cells in the sinusoids ${ }^{2,10-12}$. Most likely, the discrepancies are due to different interpretations of the specificity and recombination efficiency of the Cre lines used, given the large overlap among these cell populations ${ }^{8,9}$. On the other hand, CAR cells are defined by Cxcl12 expression, essentially coincide with $\mathrm{LEPR}^{+}$cells and Nes-GFPdim cells, and are located throughout the $\mathrm{BM}^{1,7}$.

The BM is highly innervated by various types of nerves, of which the autonomic branch is predominant ${ }^{13}$. Sympathetic nerve fibers enter the $\mathrm{BM}$ through the nutrient foramen and are closely associated with the blood vessels, before sprouting and innervating different $\mathrm{BM}$ regions ${ }^{14}$, although some nerves may reach the $\mathrm{BM}$ associated with transcortical vessels in bone. The sympathetic nervous system (SNS) has been demonstrated to regulate various hematopoietic cell functions directly or indirectly mainly via the stromal cells, mediated by neurotransmitters binding to beta adrenergic receptors $(\beta \text {-ADRs })^{13}$. $\beta$-ADRs are coupled with $\mathrm{G}_{\mathrm{s}}$ trimeric proteins and activate adenylate cyclase, catalyzing the formation of cyclic adenosine monophosphate, which subsequently activates protein kinase A phosphorylation of the receptor ${ }^{15}$. Contrastingly, the presence of the parasympathetic nervous system (PNS), another branch of the SNS, within the BM is vastly unexplored. The PNS uses acetylcholine (ACh) as the main neurotransmitter, which binds to muscarinic or nicotinic receptors. One study suggested that the PNS may innervate the distal femoral metaphysis ${ }^{16}$ and another similarly supported cholinergic innervation within the BM of rats $^{17}$. However, additional neuroanatomical evidence of parasympathetic BM innervation is essentially lacking ${ }^{18}$. Moreover, the bone anabolic effect of the $\mathrm{PNS}^{16}$ was suggested by another group to be indirectly mediated through the inhibition of central sympathetic tone ${ }^{19}$. Therefore, clarification on whether the PNS innervates the BM is required. Overall, little is known about how parasympathetic or, more broadly, cholinergic signaling might influence either HSCs or their BM niches.

\section{Bone marrow hematopoietic stem cell niche: location matters}

The dissection of $\mathrm{BM}$ niches is still a developing area because of the dynamic features of the niches to meet the physiological demands and their alterations in different scenarios such as aging, malignancies, or response to stress. Single-cell studies have provided insights into the heterogeneity of the stromal cells, forming an increasingly complex picture ${ }^{20-22}$. In addition, HSCs themselves are functionally and molecularly heterogeneous ${ }^{23-25}$, raising the possibility that distinct subpopulations of HSCs are regulated by specialized niches.

It is possible that distinct vascular niches can orchestrate the balance between quiescence and proliferation of HSCs, which is necessary for homeostasis but also regeneration of the BM following injury. Consequently, studies have investigated how the regulation of HSCs differs depending on whether they are located within the endosteal region or the central marrow. In particular, these differences become more apparent under stress conditions. Following irradiation, HSCs tend to home to the endosteal region and HSCs isolated from this region exhibit greater in vivo homing and reconstitution potential than HSCs located in the central marrow ${ }^{26-28}$.

Furthermore, it has been demonstrated that the endosteal region is important to preserve HSC quiescence under proliferative stress and to support regeneration of the HSC pool following injury $^{29-31}$. The stromal cell populations within the endosteal region better resist myeloablation, and $\mathrm{N}$-cadherin ${ }^{+} \mathrm{MSCs}^{31}$ and $\mathrm{CD} 3^{+} \mathrm{MSCs}^{32}$ have been identified as resistant cell populations that contribute to hematopoietic stem and progenitor cell (HSPC) engraftment and subsequent hematopoietic recovery. Reserve HSCs and primed HSCs have been distinguished by their proliferation and sensitivity to chemotherapy (5-fluorouracil). Notably, whereas primed HSCs tend to be located within the central BM niche, reserve HSCs are preferentially maintained in the endosteal region ${ }^{31}$. Reserve HSCs are able to resist chemotherapy in part due to N-cadherin ${ }^{+}$MSCs, which expand and produce cytokines to aid recovery after myeloablation ${ }^{31}$. Overall, these studies confirm that the endosteal BM region is important for mediating hematopoietic regeneration after stress. 


\section{Neuronal regulation under steady state}

Neuronal regulation of hematopoietic stem cells

Cumulative evidence indicates that the SNS regulates the proliferation and differentiation of HSPCs, and the migration of HSPCs and leukocytes between the BM and extramedullary sites. This was initially suggested because catecholamine levels in the blood and the BM adhered to circadian rhythms that also affected the proliferation of BM cells that expressed catecholamine receptors ${ }^{33}$. More recently, Golan et al. demonstrated in mice that a morning peak of norepinephrine and TNF induces vascular permeability, temporarily increases reactive oxygen species (ROS) levels and facilitates HSPC proliferation, differentiation and migration. Whereas, at night, a second TNF peak increases melatonin secretion and reduces vascular permeability and HSPC ROS levels, facilitating HSPC maintenance ${ }^{34}$.

A neurally-driven circadian release of HSCs and leukocytes into circulation occurs during the resting period, following photic cues $^{35}$. Leukocytes are also recruited to many vital organs, including skeletal muscle, following circadian oscillations of neural activity ${ }^{36}$. Noradrenaline binding to $\beta_{3}$-ADR on stromal cells causes a decrease in the nuclear content of Sp1 transcription factor and finally downregulation of $\mathrm{Cxcl}_{12} 2^{35}$. The interaction of $\mathrm{Cxcl12}$ expressed by stromal cells with its receptor Cxcr4, located on HSCs and leukocytes, is pivotal for HSC/ leukocyte retention in the $\mathrm{BM}^{37}$. It has also been demonstrated that the bone itself is an important transducer of signals emanating from the nervous system leading to HSC mobilization ${ }^{38,39}$.

We recently demonstrated how parasympathetic cholinergic signals coordinate with sympathetic signals to regulate the egress and homing of HSPCs and leukocytes in mice ${ }^{40}$. At night, the PNS acts centrally to dampen the noradrenergic sympathetic branch and decrease BM egress of HSPCs and leukocytes mediated through $\beta_{3}-\mathrm{ADR}^{40}$. In contrast, epinephrine released at night in circulation can stimulate $\beta_{2}$-ADR and increase vascular adhesion and subsequent $\mathrm{BM}$ homing at night ${ }^{40}$. In the morning, a novel cholinergic sympathetic branch regulates vascular adhesion and $\beta_{3}$-ADR expression ${ }^{40}$. These results illustrate how a master rheostat SNS regulates the daily migration of HSCs and leukocytes.

\section{Glial cells}

Glial cells supporting BM nerve fibers have also been suggested to regulate HSC proliferation ${ }^{41}$. Non-myelinating Schwann cells wrap around the sympathetic nerves travelling along the vasculature within the BM. Non-myelination Schwann cells have been reported to maintain HSC quiescence via secretion of tumor growth factor beta (TGF- $\beta$ ) activator molecules and induction of TGF- $\beta$ /SMAD signaling in $\mathrm{HSCs}^{41}$. This signaling contributes to HSC quiescence through increased phosphorylation of Smad2 and $\mathrm{Smad}^{41}$, hence supporting the maintenance and self-renewal of $\mathrm{HSCs}^{42}$.

\section{Effects of muscarinic signaling on hematopoiesis}

So far, the studies addressing cholinergic regulation of hematopoiesis have focused mostly on muscarinic receptor signaling.
One study demonstrated that cholinergic receptor muscarinic 4 (CHRM4) regulated self-renewal of early erythroid progenitors, and muscarinic receptor antagonists have been proposed as a therapy for treating anemia ${ }^{43}$. Pierce et al. uncovered another pathway connecting the brain with the BM to regulate mobilization of $\mathrm{HSCs}$ enforced by granulocyte colony-stimulating factor (G-CSF) ${ }^{44}$. The authors demonstrated how the muscarinic receptor type 1 (Chrm1) signaling in the hypothalamus promoted G-CSF-induced HSC mobilization via the hypothalamic-pituitary-adrenal (HPA) axis ${ }^{44}$. Thus, priming HSC migration through glucocorticoid (GC) hormone levels, which exhibit circadian oscillations, and binding to the receptor $\mathrm{Nr} 3 \mathrm{c} 1$ regulates G-CSF-induced HSC mobilization ${ }^{44}$. Whereas these studies have uncovered the influence of muscarinic signaling on HSCs, further investigation of other cholinergic signaling pathways (particularly involving nicotinic receptors) possibly influencing HSCs is warranted.

\section{Neuronal hematopoietic stem cell regulation under stress}

Hematological stress can be caused as a result of a diverse range of factors from psychological stress to hematological malignancies. However, one common consequence is the dysregulation of the SNS, predominantly affecting myelopoiesis. The following sections discuss current studies of neuronal regulation of HSCs under various stress conditions.

\section{Immunity}

Leukocytes exit the blood following circadian rhythms and undergo extensive interactions with endothelial cells as they migrate between the BM and extramedullary sites. The expression of adhesion molecules, chemokines and their receptors follow daily rhythms that regulate the migration of leukocyte subsets within distinct vascular beds. Ablation of the transcription factor BMAL1, which is an essential for clock gene, demonstrated that rhythmic leukocyte recruitment is dependent on both cellautonomous and microenvironmental oscillations ${ }^{45}$. Under stress conditions (e.g. jetlag or transplantation), alterations in these rhythms can have physiological consequences by disrupting hematopoietic cell recruitment and recovery. Therefore, timebased therapeutics for transplantations and inflammatory diseases may prove beneficial ${ }^{36}$. In addition, leukocyte adhesion to arteries and veins is disproportionately disrupted following an inflammatory response, with arteries driving rhythmic inflammatory responses within the vasculature ${ }^{46}$. Altogether, these studies suggest an important influence of circadian rhythms in immune response.

Mak and Tracey's laboratories have pioneered research into how neural signals regulate immunity by showing that norepinephrine-induced $\mathrm{T}$ cell-derived $\mathrm{ACh}$ regulates immune response $^{47-50}$. Recently, they have demonstrated that ChAT is induced in both $\mathrm{CD}^{+}$and $\mathrm{CD}^{+} \mathrm{T}$ cells during infection in an interleukin-21 (IL-21)-dependent manner and is key for overcoming infections ${ }^{47}$. Moreover, they have validated that ChAT is expressed and ACh is produced by B cells following stimulation with sulphated cholecystokinin, resulting in 
controlled recruitment of neutrophils ${ }^{48}$. In the proposed circuit, the vagus nerve acts via the splenic nerve, which releases ACh from T cells. ACh binds to the nicotinic ACh receptor $\alpha 7$ subunit on macrophages, causing the inhibition of tumor necrosis factor release, thus regulating inflammation ${ }^{49}$. The vagus nerve-to-spleen circuit can also be controlled at a central level and can be exploited to suppress pro-inflammatory cytokine release $^{51,52}$. Overall, these studies suggest the importance of the cholinergic vagus nerve-to-spleen anti-inflammatory pathways. However, it is important to mention that other groups have suggested alternative ways to explain the cholinergic anti-inflammatory reflex. Particularly, the efferent arm of the inflammatory reflex seems to involve a different splanchnic anti-inflammatory pathway ${ }^{53}$.

\section{Impact of the autonomic nervous system on the skeleton}

Apart from the direct regulation of hematopoietic cells and their niches, it is likely that circadian oscillation of neural activity indirectly regulates hematopoiesis and immunity through their effects on bone remodeling. Skeletal remodeling comprises two phases: resorption by osteoclasts and formation by osteoblasts, allowing vertebrates to regulate bone mass daily. Osteoblasts are multifunctional cells able to control osteoclast differentiation. Notably, the energy expenditure hormone leptin inhibits bone formation through a neuronal relay. Sympathetic signaling via $\beta_{2}$-ADR on osteoblasts regulate their proliferation and control bone formation downstream of leptin ${ }^{54}$. The SNS favors bone resorption by increasing the expression of Rankl on osteoblast progenitor cells, which regulates osteoclast differentiation. Moreover, leptin regulates the expression of the neuropeptide cocaine amphetamine regulated transcript (CART), which inhibits bone resorption by controlling Rankl expression ${ }^{55}$.

In addition, osteoclast function is inhibited by cholinergic parasympathetic signals that inhibit sympathetic tone centrally ${ }^{19}$. The skeleton can in turn modulate neural activity through secretion of the hormone osteocalcin, which regulates parasympathetic tone $^{56}$. Therefore, it is likely there is an interplay between sympathetic and parasympathetic nervous systems to regulate bone remodeling and stress responses. These pathways, which could have potential therapeutic implications for several complex disorders including osteoporosis, chronic fatigue and fracture repair ${ }^{57}$, may also profoundly impact hematopoiesis.

\section{Cardiovascular disease}

Ischemic myocardium causes the heart to initiate the influx of circulating myeloid cells to the site of damage. In turn, this results in the SNS signaling to the BM to increase the production of leukocytes to meet the demand, aided by circulating mediators such as granulocyte-macrophage colony-stimulating factor (GM-CSF) and IL-1 $\beta$ produced by the heart ${ }^{58-61}$. Therefore, the SNS regulates inflammation in cardiovascular disease by controlling HSPC proliferation and differentiation in response to stress. In addition, it was recently demonstrated that patients who exhibit recurrent myocardial infarction have a dampened emergency hematopoiesis response, due to long-term reprogramming of myeloid progenitors from the first myocardial infarction, resulting in fewer leukocytes being recruited to the site of injury ${ }^{62}$. Consequently, this is a potentially important factor to consider when selecting therapies for recurrent myocardial infarction ${ }^{62}$.

\section{Social and psychological stress}

Both social and chronic psychological stress have been demonstrated to lead to SNS-induced upregulation of myelopoiesis in mice and subsequently to increases in the production of pro-inflammatory cytokines ${ }^{63,64}$. These effects were reversed with the treatment of propranolol, which is a non-selective beta blocker ${ }^{63,64}$. Following on from those studies and previous studies on adrenergic HSC regulation ${ }^{35}$, chronic psychosocial stress was demonstrated to act on the most primitive progenitors, causing an increase in the proliferation of HSPCs in the BM of mice $^{65}$. This finding translated to the human setting, where it was observed that chronic stress induced monocytosis and neutrophilia in humans ${ }^{65}$. This was due to the activation of the SNS, causing an increase in catecholamine levels, which activate the $\beta_{3}-\mathrm{ADR}$ on $\mathrm{BM}$ niche cells, resulting in a decrease in CXCL12 levels ${ }^{35}$. The HSC mobilization to peripheral circulation and the spleen, and the subsequent myeloid expansion in the spleen can aggravate chronic inflammatory diseases such as atherosclerosis $^{58,66}$.

\section{Burn injury}

In the context of burn patients, who receive multiple blood transfusions for the treatment of anemia, increased catecholamine levels induced expansion of HSPCs and increased their myeloid regulatory transcription factor (MafB) expression, causing a myeloid shift at the expense of megakaryocyte-erythrocyte progenitors ${ }^{67}$. Chronic propranolol treatment restored the expansion of these cells but also influenced the myelo-erythroid bifurcation by reducing the granulocyte-monocyte progenitors and increasing megakaryocyte-erythroid progenitor cells in the BM of burn-stressed mice ${ }^{67}$. These observations translated to the human setting, where ex vivo culture of burn patient peripheral blood mononuclear cells also demonstrated that their commitment stage of erythropoiesis was impaired and could be restored with propranolol ${ }^{67}$. Consequently, beta-adrenergic blockers exhibit therapeutic value for burn patients by redirecting the hematopoietic commitment toward erythroid lineage via decreased MafB expression in multipotent progenitors, leading to increased erythropoietin responsiveness ${ }^{67}$. How these forms of stress affect hematopoiesis through the nervous system is summarized in Table 1.

\section{Aging}

The hematopoietic system is disrupted upon aging, resulting in the increase of HSCs which are functionally impaired ${ }^{68,69}$. These changes are caused by both cell-intrinsic dysregulation and remodeling of the $\mathrm{BM}$ microenvironment ${ }^{70,71}$. One of the hallmarks of hematopoietic aging is that the myeloid output of HSCs increases at the expense of lymphopoiesis ${ }^{68,69}$. One 


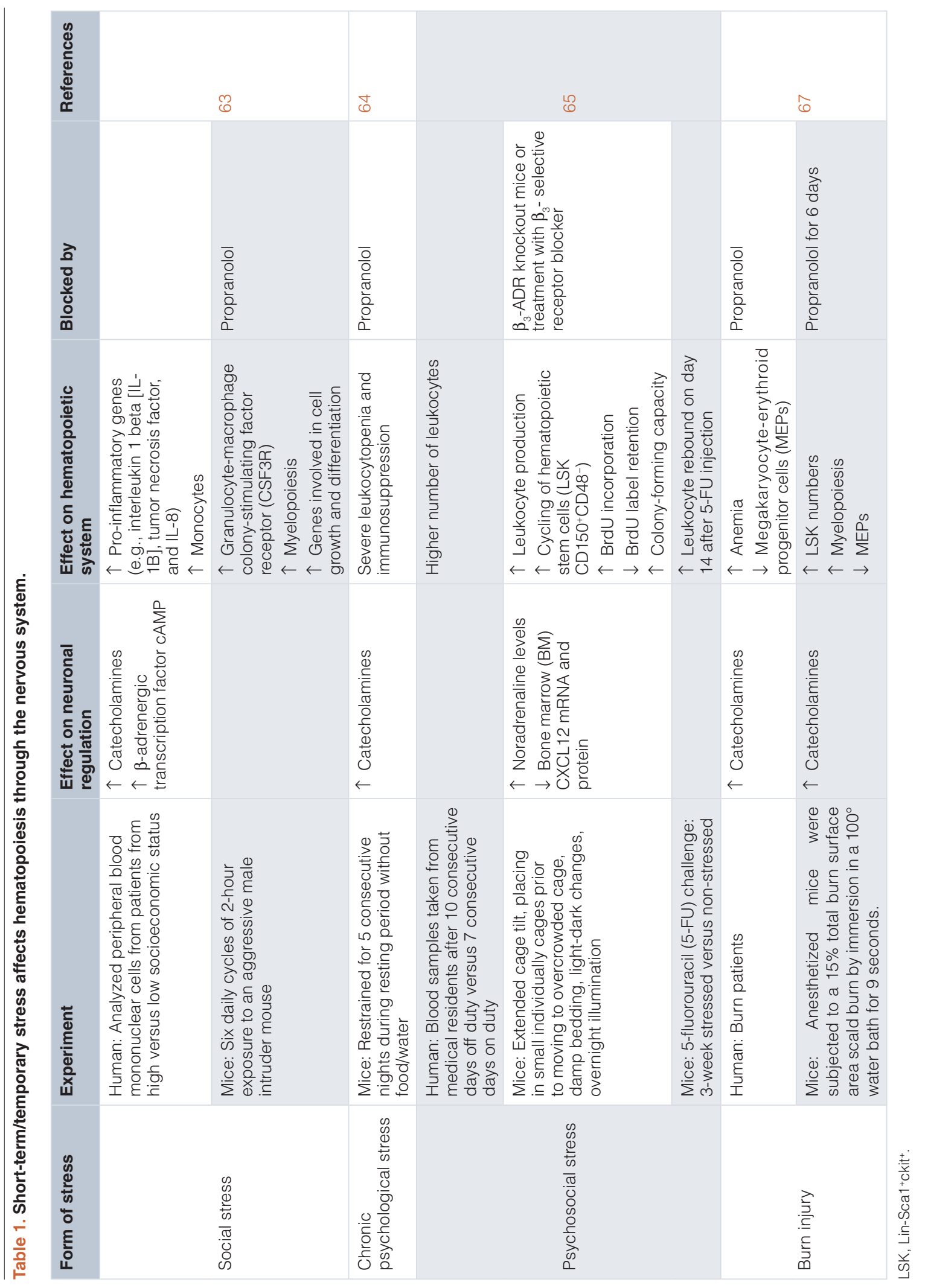


study carried out transplantations of old HSCs into young recipients and vice versa. The young microenvironment was able to reduce myelopoiesis, confirming the contribution of the microenvironment ${ }^{72}$. We recently noted that the SNS is actively involved in aging of the hematopoietic system. Our recent study demonstrated that sympathetic noradrenergic fibers marked by tyrosine hydroxylase (Th) increased in the mouse BM with aging ${ }^{6}$. Increased $\beta_{2}$-adrenergic signaling in expanded central BM niches promoted myeloid cell expansion ${ }^{6}$. A functional switch of neurotransmission, favoring $\beta_{2}$-ADR over $\beta_{3}$-ADR signaling during aging, appears to favor myeloid cell expansion through the regulation of the $\mathrm{BM}$ microenvironment ${ }^{6}$. An active role for the nervous system in aging is supported by the increased basal sympathetic tone during human aging ${ }^{73-75}$ and by a recent study indicating that increased excitatory neurotransmission reduces the life $\operatorname{span}^{76}$. In contrast, another study suggested that $\mathrm{BM} \mathrm{Th}^{+}$fibers were reduced (not increased) during aging and that surgical denervation of young BM increased myelopoiesis ${ }^{77}$. However, BM noradrenergic nerve fibers appear to decrease from youth to adulthood (8-month-old adult mice compared with 2-month-old mice; Supplementary Figure $5 \mathrm{~b}$ in $\mathrm{REF}^{77}$ ) but these fibers appear increased (not decreased) in old (20month-old) mice 6 . Moreover, the possible contribution of the inflammation caused by experimental surgical denervation to the hematopoietic aging phenotypes ${ }^{77}$ should be considered.

\section{Diabetes}

The disautonomia associated with diabetes has been shown to affect the BM, disrupt the peripheral clock, and compromise G-CSF-induced HSC mobilization in experimental models because of the HSC niche deregulation ${ }^{78,79}$. In humans, cardiovascular diabetic autonomic neuropathy correlates with decreased circulating HSPCs with increased $66-\mathrm{kDa}$ protein from the src homology and collagen homology domain (p66Shc) and reduced expression of sirtuin $1(\text { Sirt } 1)^{80}$.

\section{Hematopoietic recovery following radiation}

Ionizing radiation and chemotherapy used to treat cancer cause BM injury and alter the BM cellular composition. Following chemotherapy, there is an increase in apoptosis of mature cells along with progenitor cells that are cycling. Chemotherapy can damage BM innervation ${ }^{81}$ and catecholamines, namely norepinephrine can improve hematopoietic reconstitution following chemotherapy in mice ${ }^{81,82}$. Furthermore, G-CSF and GM-CSF are commonly used to accelerate myelopoiesis and minimize the burden of chemotherapy. These cytokines upregulate the expression of neuronal receptors on HSPCs, allowing for them to form a greater response to neurotransmitters, leading to enhanced proliferation and motility of human $\mathrm{CD}_{3} 4^{+}$progenitor cells and subsequent repopulation of mouse $\mathrm{BM}^{83}$. Additionally, mitotically active Nestin-GFP ${ }^{+}$perisinusoidal niche cells are greatly diminished whereas the Nestin-GFP ${ }^{+}$peri-arteriolar niche cells exhibit greater chemoresistance because of their higher quiescence ${ }^{2}$.
Consequently, the use of adrenergic agents as a therapeutic approach should be investigated further, adding to the available evidence on $\alpha 1$-ADR agonists or $\beta$-ADR agonists ${ }^{81,82,84}$.

\section{Hematological malignancies}

The SNS has also been implicated in the development of hematological malignancies, predominantly the progression of myeloid malignancies. Sympathetic neuropathy occurs in the development of both acute myelogenous leukemia (AML) and myeloproliferative neoplasms $(\mathrm{MPNs})^{85,86}$, but the consequences appear to be different. In MPN, IL-1 $\beta$ produced by the mutant hematopoietic cells damages sensitive HSC niche components, such as neural terminals, Schwann cells, and Nestin ${ }^{+}$ $\mathrm{MSCs}^{86}$. In contrast, experimental AML causes the reduction in arteriole-associated $\mathrm{NG}^{+}$cell numbers and correlates with the expansion of Nestin-GFP ${ }^{+}$stromal cells ${ }^{85}$. In MPN, chronic administration of $\beta_{3}$-adrenergic agonists to compensate for the defective innervation can rescue $\mathrm{Nestin}^{+}$niche cells and improve myelofibrosis (BM scarring hampering normal hematopoiesis) in both mice ${ }^{86}$ and humans ${ }^{87}$. Different effects of $\beta_{3}$-adrenergic agonists in mouse models and human MPN might be explained by the different drugs or dosing used. In AML, the relevance of sympathetic neuropathy ${ }^{85}$ remains to be demonstrated in humans. The changes in sympathetic regulation of HSC niches during aging and age-related myeloid malignancies are briefly summarized in Figure 1.

\section{Conclusions and future perspectives}

The BM is regulated by neural signals principally emerging from the autonomic nervous system. The sympathetic noradrenergic branch has been much more explored than the parasympathetic (cholinergic) branch, both under steady state and during stress hematopoiesis. The data available suggest that sympathetic innervation regulates BM homeostasis but is especially important to respond to stress scenarios. Recent evidence suggests that the cholinergic branch of the autonomic nervous system contributes to this regulation ${ }^{40}$. However, the roles of this cholinergic branch (sympathetic or parasympathetic) in the regulation of hematopoiesis remain largely unexplored.

During chronic inflammation, cardiovascular disease, and shortterm social and psychological stress, beta blockers have been demonstrated to revert excessive myelopoiesis. Whether a similar strategy could be proposed to prevent excessive myeloid cell production during aging or age-related myeloid malignancies requires further investigation. The possible contribution of other adrenergic or cholinergic signaling pathways to the progression of hematological disorders is an exciting area for future investigation.

\section{Abbreviations}

$\mathrm{ACh}$, acetylcholine; ADR, adrenergic receptor; AML, acute myelogenous leukemia; BM, bone marrow; CAR, Cxcl12-abundant reticular; ChAT, choline acetyltransferase; G-CSF, granulocyte colony-stimulating factor; HSC, hematopoietic stem cell; 


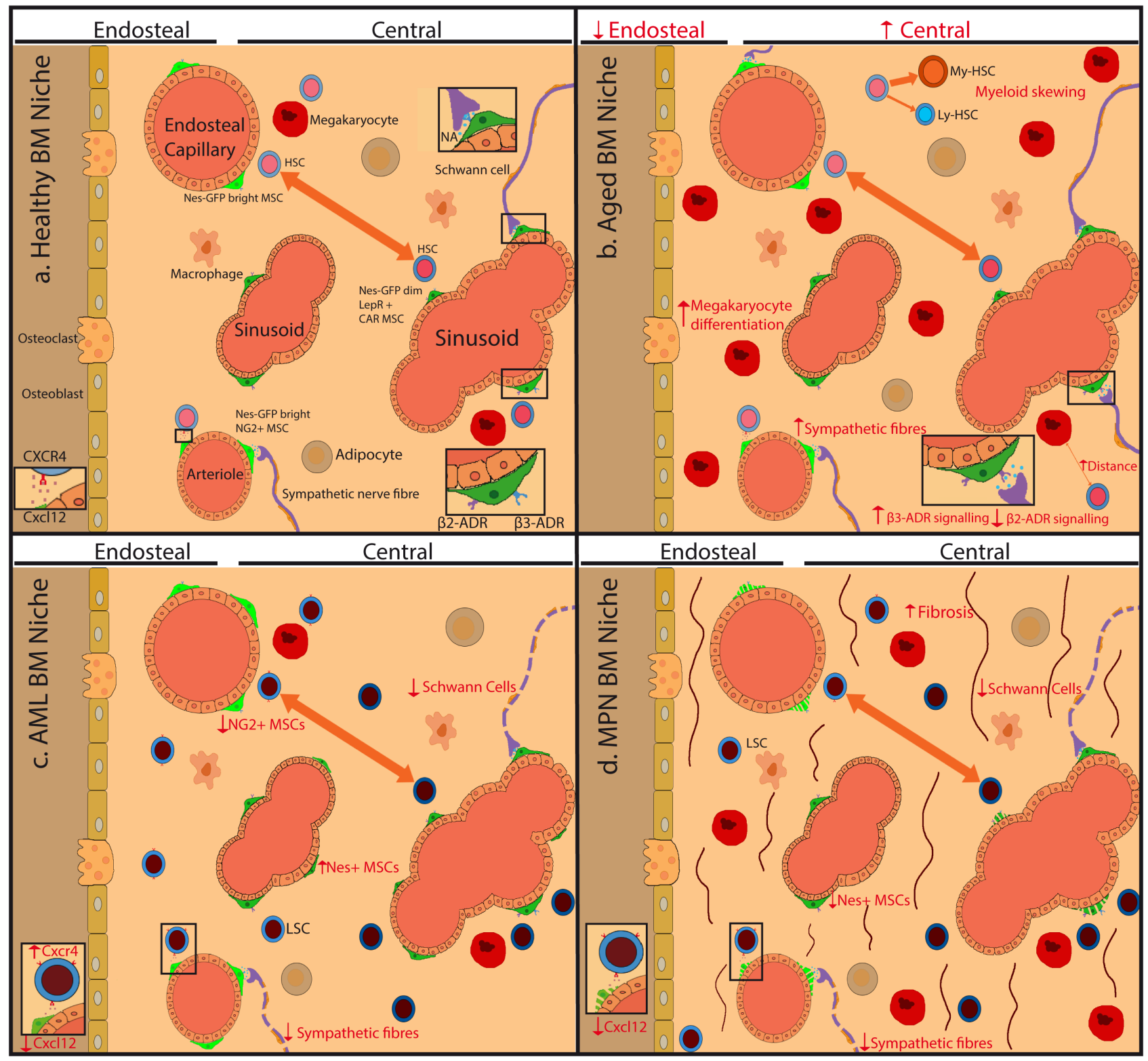

Figure 1. Model illustrating hematopoietic stem cell niche alterations with aging and age-related myeloid malignancies. Scheme shows key hematopoietic stem cell (HSC) niche cell types and their alterations during aging and age-related myeloid malignancies. (a) Mesenchymal stem cells (MSCs), which can differentiate into osteoblasts or adipocytes, regulate HSCs in endosteal niches enriched in transition zone capillaries or in central niches enriched in sinusoids. Nestin-green fluorescent protein (Nes-GFP) ${ }^{\text {bright }}$ neural-glial antigen 2 (NG2)+ MSCs are associated with endosteal capillaries and arterioles located throughout the bone marrow (BM), whereas Nes-GFPdim leptin receptor (LEPR) ${ }^{+}$ CXC-chemokine ligand 12 (CXCL12)-abundant reticular (CAR) MSCs are associated with sinusoids in the central BM. Sympathetic nerve fibers regulate CXCL12 expression in MSCs and the migration of HSCs through the sinusoids. Different MSC subpopulations, endothelial cells, non-myelinating Schwann cells, and megakaryocytes contribute to regulate HSC proliferation. (b) During mouse aging, sympathetic fibers increase, but $\beta_{3}$-adrenergic signaling is reduced, whilst $\beta_{2}$-adrenergic signaling increases promoting myeloid skewing. Megakaryocytes increase but locate further away from HSCs. (c, d) In myeloid malignancies, a damage to this neural regulation of MSCs might contribute to disease progression. (c) In acute myeloid leukemia (AML), sympathetic nerve fibers and NG2+ Nes-GFPbright MSCs decrease, whilst Nes-GFPdim MSCs increase, although the implications for human AML are unknown. (d) In MPN, the neuroglial damage leads to apoptosis of Nestin-GFP+ MSCs, which can be rescued through chronic treatment with sympathicomimetic drugs that indirectly improve reticulin fibrosis in mice and humans. ADR, adrenergic receptor, NA, noradrenaline. 
HSPC, hematopoietic stem and progenitor cell; IL, interleukin; LepR, leptin receptor; MafB, myeloid regulatory transcription factor; MPN, myeloproliferative neoplasm; MSC, mesenchymal stem cell; NG2, neuron-glial antigen; PNS, parasympathetic nervous system; SNS, sympathetic nervous system; Th, tyrosine hydroxylase
Acknowledgments

The authors thank the SMF group and the Faculty Opinions editorial board and reviewers for their constructive discussions. The authors apologize for the omission of relevant literature due to space limitations.
1. FAcar M, Kocherlakota KS, Murphy MM, et al:: Deep imaging of bone marrow shows non-dividing stem cells are mainly perisinusoidal. Nature. 2015; 526(7571): 126-30

PubMed Abstract | Publisher Full Text | Free Full Text |

Faculty Opinions Recommendation

2. $\mathrm{F}$ Kunisaki $\mathrm{Y}$, Bruns I, Scheiermann C, et al:: Arteriolar niches maintain haematopoietic stem cell quiescence. Nature. 2013; 502(7473): 637-43. PubMed Abstract | Publisher Full Text | Free Full Text | Faculty Opinions Recommendation

3. F Kusumbe AP, Ramasamy SK, Adams RH: Coupling of angiogenesis and osteogenesis by a specific vessel subtype in bone. Nature. 2014; 507(7492): 323-8.

PubMed Abstract | Publisher Full Text | Free Full Text | Faculty Opinions Recommendation

4. Itkin T, Gur-Cohen S, Spencer JA, et al:: Distinct bone marrow blood vessels differentially regulate haematopoiesis. Nature. 2016; 532(7599): 323-8. PubMed Abstract | Publisher Full Text | Free Full Text

5. F Gruneboom A, Hawwari I, Weidner D, et al:: A network of trans-cortical capillaries as mainstay for blood circulation in long bones. Nat Metab. 2019; 1(2): $236-50$

PubMed Abstract | Publisher Full Text | Free Full Text

Faculty Opinions Recommendation

6. Ho YH, Del Toro R, Rivera-Torres J, et al: Remodeling of Bone Marrow Hematopoietic Stem Cell Niches Promotes Myeloid Cell Expansion during Premature or Physiological Aging. Cell Stem Cell. 2019; 25(3): 407-18. PubMed Abstract | Publisher Full Text | Free Full Text

7. $\mathrm{F}$ Omatsu $\mathrm{Y}$, Sugiyama $\mathrm{T}$, Kohara $\mathrm{H}$, et al:: The essential functions of adipoosteogenic progenitors as the hematopoietic stem and progenitor cell niche. Immunity. 2010; 33(3): 387-99.

PubMed Abstract | Publisher Full Text | Faculty Opinions Recommendation

8. Mendez-Ferrer S: Molecular interactome between HSCs and their niches. Blood. 2019; 134(15): 1197-8. PubMed Abstract | Publisher Full Text

9. $\quad \mathrm{F}$ Mende N, Jolly A, Percin Gl, et al:: Prospective isolation of nonhematopoietic cells of the niche and their differential molecular interactions with HSCs. Blood. 2019; 134(15): 1214-26. PubMed Abstract | Publisher Full Text | Faculty Opinions Recommendation

10. F Asada N, Kunisaki $\mathrm{Y}$, Pierce $\mathrm{H}$, et al.: Differential cytokine contributions of perivascular haematopoietic stem cell niches. Nat Cell Biol. 2017; 19(3): 214-23. PubMed Abstract | Publisher Full Text | Free Full Text Faculty Opinions Recommendation

11. F Comazzetto S, Murphy MM, Berto S, et al.: Restricted Hematopoietic Progenitors and Erythropoiesis Require SCF from Leptin Receptor+ Niche Cells in the Bone Marrow. Cell Stem Cell. 2019; 24(3): 477-86.e6. PubMed Abstract | Publisher Full Text | Free Full Text Faculty Opinions Recommendation

12. F Ding L, Saunders TL, Enikolopov G, et al: Endothelial and perivascular cells maintain haematopoietic stem cells. Nature. 2012; 481(7382): 457-62. PubMed Abstract Publisher Full Text | Free Full Text Faculty Opinions Recommendation

13. del Toro R, Mendez-Ferrer S: Autonomic regulation of hematopoiesis and cancer. Haematologica. 2013; 98(11): 1663-6.

PubMed Abstract | Publisher Full Text | Free Full Text

14. Calvo $\mathrm{W}$ : The innervation of the bone marrow in laboratory animals. Am $J$ Anat. 1968; 123(2): 315-28.

PubMed Abstract | Publisher Full Text

15. Rosenbaum DM, Rasmussen SG, Kobilka BK: The structure and function of Gprotein-coupled receptors. Nature. 2009; 459(7245): 356-63. PubMed Abstract | Publisher Full Text | Free Full Text

16. Bajayo A, Bar A, Denes A, et al:: Skeletal parasympathetic innervation communicates central IL-1 signals regulating bone mass accrual. Proc Natl Acad Sci U S A. 2012; 109(38): 15455-60

PubMed Abstract | Publisher Full Text | Free Full Text
17. Artico M, Bosco S, Cavallotti C, et al.: Noradrenergic and cholinergic innervation of the bone marrow. Int J Mol Med. 2002; 10(1): 77-80.

PublMed Abstract I Publisher Full Text

18. Nance DM, Sanders VM: Autonomic innervation and regulation of the immune system (1987-2007). Brain Behav Immun. 2007; 21(6): 736-45.

PubMed Abstract | Publisher Full Text | Free Full Text

19. Shi $Y$, Oury F, Yadav VK, et al.: Signaling through the $M(3)$ muscarinic receptor favors bone mass accrual by decreasing sympathetic activity. Cell Metab. 2010; 11(3): 231-8

PubMed Abstract | Publisher Full Text | Free Full Text

20. F Tikhonova AN, Dolgalev I, Hu H, et al:: The bone marrow microenvironment at single-cell resolution. Nature. 2019; 569(7755): 222-8. PubMed Abstract | Publisher Full Text | Free Full Text | Faculty Opinions Recommendation

21. F Baryawno N, Przybylski D, Kowalczyk MS, et al:: A Cellular Taxonomy of the Bone Marrow Stroma in Homeostasis and Leukemia. Cell. 2019; 177(7): 1915-32.e16.

PubMed Abstract | Publisher Full Text | Free Full Text | Faculty Opinions Recommendation

22. F Baccin C, Al-Sabah J, Velten L, et al:: Combined single-cell and spatial transcriptomics reveal the molecular, cellular and spatial bone marrow niche organization. Nat Cell Biol. 2020; 22(1): 38-48. PubMed Abstract | Publisher Full Text | Faculty Opinions Recommendation

23. F Laurenti E, Gottgens B: From haematopoietic stem cells to complex differentiation landscapes. Nature. 2018; 553(7689): 418-26. PubMed Abstract | Publisher Full Text | Free Full Text | Faculty Opinions Recommendation

24. F Dykstra B, Kent D, Bowie M, et al.: Long-term propagation of distinct hematopoietic differentiation programs in vivo. Cell Stem Cell. 2007; 1(2): hemato $218-29$. 218-29.
PubMed Abstract | Publisher Full Text | Faculty Opinions Recommendation

25. F Yamamoto R, Morita $\mathrm{Y}$, Ooehara J, et al.: Clonal analysis unveils selfrenewing lineage-restricted progenitors generated directly from hematopoietic stem cells. Cell. 2013; 154(5): 1112-26.

PubMed Abstract | Publisher Full Text | Faculty Opinions Recommendation

26. F Lo Celso C, Fleming HE, Wu JW, et al.: Live-animal tracking of individual haematopoietic stem/progenitor cells in their niche. Nature. 2009; 457(7225): 92-6.

PubMed Abstract | Publisher Full Text | Free Full Text |

Faculty Opinions Recommendation

27. F Adams GB, Chabner KT, Alley IR, et al:: Stem cell engraftment at the endosteal niche is specified by the calcium-sensing receptor. Nature. 2006; 439(7076): 599-603.

PubMed Abstract | Publisher Full Text | Faculty Opinions Recommendation

28. Nilsson SK, Johnston HM, Coverdale JA: Spatial localization of transplanted hemopoietic stem cells: inferences for the localization of stem cell niches. Blood. 2001; 97(8): 2293-9.

PubMed Abstract | Publisher Full Text

29. Silberstein L, Goncalves KA, Kharchenko PV, et al: Proximity-Based Differential Single-Cell Analysis of the Niche to Identify Stem/Progenitor Cell Regulators. Cell Stem Cell. 2016; 19(4): 530-543. PubMed Abstract | Publisher Full Text | Free Full Text

30. $\mathrm{F}$ Zhao M, Tao F, Venkatraman A, et al:: N-Cadherin-Expressing Bone and Marrow Stromal Progenitor Cells Maintain Reserve Hematopoietic Stem Cells. Cell Rep. 2019; 26(3): 652-69.e6.

PubMed Abstract | Publisher Full Text | Free Full Text | Faculty Opinions Recommendation

31. F Chen Q, Liu Y, Jeong HW, et al:: Apelin * Endothelial Niche Cells Control Hematopoiesis and Mediate Vascular Regeneration after Myeloablative Injury. Cell Stem Cell. 2019; 25(6): 768-83.e6.

PubMed Abstract | Publisher Full Text | Free Full Text |

Faculty Opinions Recommendation 
32. F Severe N, Karabacak NM, Gustafsson K, et al:: Stress-Induced Changes in Bone Marrow Stromal Cell Populations Revealed through Single-Cell Protein Expression Mapping. Cell Stem Cell. 2019; 25(4): 570-83.e7. PubMed Abstract | Publisher Full Text | Free Full Text Faculty Opinions Recommendation

33. Maestroni GJ, Cosentino M, Marino F, et al: Neural and endogenous catecholamines in the bone marrow. Circadian association of norepinephrine with hematopoiesis? Exp Hematol. 1998; 26(12): 1172-7. PubMed Abstract

34. F Golan K, Kumari A, Kollet O, et al:: Daily Onset of Light and Darkness Differentially Controls Hematopoietic Stem Cell Differentiation and Maintenance. Cell Stem Cell. 2018; 23(4): 572-85.e7. PubMed Abstract | Publisher Full Text | Faculty Opinions Recommendation

35. F Mendez-Ferrer S, Lucas D, Battista M, et al:: Haematopoietic stem cell release is regulated by circadian oscillations. Nature. 2008; 452(7186): 442-7. PubMed Abstract | Publisher Full Text | Faculty Opinions Recommendation

36. F Scheiermann C, Kunisaki Y, Lucas D, et al:: Adrenergic nerves govern circadian leukocyte recruitment to tissues. Immunity. 2012; 37(2): 290-301. PubMed Abstract | Publisher Full Text | Free Full Text Faculty Opinions Recommendation

37. Nagasawa T, Hirota S, Tachibana K, et al.: Defects of B-cell lymphopoiesis and bone-marrow myelopoiesis in mice lacking the CXC chemokine PBSF/SDF-1. Nature 1996; 382 (6592): 635-8. PubMed Abstract | Publisher Full Tex

38. F Katayama $Y$, Battista M, Kao WM, et al.: Signals from the sympathetic nervous system regulate hematopoietic stem cell egress from bone marrow. Cell. 2006; 124(2): 407-21.

PubMed Abstract | Publisher Full Text | Faculty Opinions Recommendation

39. F Asada N, Katayama $\mathrm{Y}$, Sato M, et al.: Matrix-embedded osteocytes regulate mobilization of hematopoietic stem/progenitor cells. Cell Stem Cell. 2013; 12(6): 737-47.

PubMed Abstract | Publisher Full Text | Faculty Opinions Recommendation

40. Garcia-Garcia A, Korn C, Garcia-Fernandez M, et al.: Dual cholinergic signals regulate daily migration of hematopoietic stem cells and leukocytes. Blood. 2019; 133(3): 224-36

PubMed Abstract | Publisher Full Text | Free Full Text

41. F Yamazaki S, Ema H, Karlsson G, et al:: Nonmyelinating Schwann cells maintain hematopoietic stem cell hibernation in the bone marrow niche. Cell. 2011; 147(5): 1146-58.

PubMed Abstract | Publisher Full Text | Faculty Opinions Recommendation

42. F Blank U, Karlsson S: TGF- $\beta$ Signaling in the Control of Hematopoietic Stem Cells. Blood. 2015; 125(23): 3542-50.

PubMed Abstract | Publisher Full Text | Faculty Opinions Recommendation

43. F Trivedi G, Inoue D, Chen C, et al:: Muscarinic acetylcholine receptor regulates self-renewal of early erythroid progenitors. Sci Transl Med. 2019; 11(511): eaaw3781

PubMed Abstract | Publisher Full Text | Free Full Text

Faculty Opinions Recommendation

44. F Pierce H, Zhang D, Magnon C, et al.: Cholinergic Signals from the CNS Regulate G-CSF-Mediated HSC Mobilization from Bone Marrow via a Glucocorticoid Signaling Relay. Cell Stem Cell. 2017; 20(5): 648-58 e4. PubMed Abstract | Publisher Full Text | Free Full Text | Faculty Opinions Recommendation

45. F He W, Holtkamp S, Hergenhan SM, et al:: Circadian Expression of Migratory Factors Establishes Lineage-Specific Signatures that Guide the Homing of Leukocyte Subsets to Tissues. Immunity. 2018; 49(6): 1175-90 e7. Leukocyte Subsets to Tissues. Immunity. 2018, 49(6): 117 Faculty Opinions Recommendation

46. F de Juan A, Ince LM, Pick R, et al:: Artery-Associated Sympathetic Innervation Drives Rhythmic Vascular Inflammation of Arteries and Veins. Circulation. 2019; 140(13): 1100-14

PubMed Abstract | Publisher Full Text | Free Full Text

Faculty Opinions Recommendation

47. F Cox MA, Duncan GS, Lin GH, et al.: Choline acetyltransferase-expressing T cells are required to control chronic viral infection. Science. 2019; 363(6427): 639-44.

PubMed Abstract | Publisher Full Text | Free Full Text |

Faculty Opinions Recommendation

48. F Reardon C, Duncan GS, Brustle A, et al.: Lymphocyte-derived ACh regulates local innate but not adaptive immunity. Proc Natl Acad Sci U S A. 2013; 110(4): $1410-5$.

PubMed Abstract | Publisher Full Text | Free Full Text Faculty Opinions Recommendation

49. Wang $\mathrm{H}, \mathrm{Yu} \mathrm{M}$, Ochani $\mathrm{M}$, et al.: Nicotinic acetylcholine receptor alpha7 subunit is an essential regulator of inflammation. Nature. 2003; 421(6921): 384-8. PubMed Abstract | Publisher Full Tex

50. F Rosas-Ballina M, Olofsson PS, Ochani M, et al:: Acetylcholine-synthesizing T cells relay neural signals in a vagus nerve circuit. Science. 2011; 334(6052): 98-101.

PubMed Abstract | Publisher Full Text | Free Full Text

Faculty Opinions Recommendation
51. F Bonaz B, Sinniger V, Pellissier S: The Vagus Nerve in the Neuro-Immune Axis: Implications in the Pathology of the Gastrointestinal Tract. Front Immunol. 2017: 8: 1452 .

PubMed Abstract | Publisher Full Text | Free Full Text |

Faculty Opinions Recommendation

52. Ji H, Rabbi MF, Labis $\mathrm{B}$, et al:: Central cholinergic activation of a vagus nerveto-spleen circuit alleviates experimental colitis. Mucosal Immunol. 2014; 7(2): 335-47.

PubMed Abstract | Publisher Full Text | Free Full Text

53. Martelli D, Yao ST, Mancera J, et al.: Reflex control of inflammation by the splanchnic anti-inflammatory pathway is sustained and independent of anesthesia. Am J Physiol Regul Integr Comp Physiol. 2014; 307(9): R1085-91. PubMed Abstract | Publisher Full Text

54. F Takeda S, Elefteriou F, Levasseur R, et al.: Leptin regulates bone formation via the sympathetic nervous system. Cell. 2002; 111(3): 305-17. PubMed Abstract | Publisher Full Text | Faculty Opinions Recommendation

55. F Elefteriou F, Ahn JD, Takeda S, et al.: Leptin regulation of bone resorption by the sympathetic nervous system and CART. Nature. 2005; 434(7032) 514-20.

PubMled Abstract | Publisher Full Text | Faculty Opinions Recommendation

56. $\quad \mathrm{F}$ Berger JM, Singh P, Khrimian L, et al:: Mediation of the Acute Stress Response by the Skeleton. Cell metabolism. 2019; 30(5): 890-902 e8. PubMed Abstract | Publisher Full Text | Free Full Text | Faculty Opinions Recommendation

57. F Elefteriou F: Impact of the Autonomic Nervous System on the Skeleton Physiol Rev. 2018; 98(3): 1083-112. PubMed Abstract | Publisher Full Text | Free Full Text | Faculty Opinions Recommendation

58. F Dutta $P$, Courties G, Wei $Y$, et al:: Myocardial infarction accelerates atherosclerosis. Nature. 2012; 487(7407): 325-9. PubMed Abstract | Publisher Full Text | Free Full Text | Faculty Opinions Recommendation

59. Dutta $\mathrm{P}$, Sager HB, Stengel KR, et al.: Myocardial Infarction Activates CCR2+ Hematopoietic Stem and Progenitor Cells. Cell Stem Cell. 2015; 16(5): 477-87. PubMed Abstract | Publisher Full Text | Free Full Text

60. F Anzai A, Choi JL, He S, et al:: The infarcted myocardium solicits GM-CSF for the detrimental oversupply of inflammatory leukocytes. J Exp Med. 2017; 214(11): 3293-310

PubMed Abstract | Publisher Full Text | Free Full Text | Faculty Opinions Recommendation

61. Sager HB, Heidt T, Hulsmans M, et al.: Targeting Interleukin-1 $\beta$ Reduces Leukocyte Production After Acute Myocardial Infarction. Circulation. 2015; 132(20): 1880-90

PubMed Abstract | Publisher Full Text | Free Full Text

62. F Cremer S, Schloss MJ, Vinegoni C, et al:: Diminished Reactive Hematopoiesis and Cardiac Inflammation in a Mouse Model of Recurrent Myocardial Infarction. J Am Coll Cardiol. 2020; 75(8): 901-15. PubMed Abstract | Publisher Full Text | Free Full Text | Faculty Opinions Recommendation

63. Powell ND, Sloan EK, Bailey MT, et al:: Social Stress Up-Regulates Inflammatory Gene Expression in the Leukocyte Transcriptome via $\beta$-Adrenergic Induction of Myelopoiesis. Proc Natl Acad Sci U S A. 2013; 110(41): 16574-9. PubMed Abstract | Publisher Full Text | Free Full Text

64. Jin J, Wang $X$, Wang $Q$, et al.: Chronic psychological stress induces the accumulation of myeloid-derived suppressor cells in mice. PLOS One. 2013; 8(9): e74497.

PubMed Abstract | Publisher Full Text | Free Full Text

65. Heidt T, Sager HB, Courties G, et al:: Chronic variable stress activates hematopoietic stem cells. Nat Med. 2014; 20(7): 754-8. PubMed Abstract | Publisher Full Text | Free Full Text

66. F Al-Sharea A, Lee MKS, Whillas A, et al:: Chronic sympathetic driven hypertension promotes atherosclerosis by enhancing hematopoiesis. Haematologica. 2019; 104(3): 456-67.

PubMed Abstract | Publisher Full Text | Free Full Text | Faculty Opinions Recommendation

67. F Hasan S, Johnson NB, Mosier MJ, et al:: Myelo-erythroid Commitment Afte Burn Injury Is Under $\beta$-Adrenergic Control via MafB Regulation. Am J Physiol Cell Physiol. 2017; 312(3): C286-C301. PubMed Abstract | Publisher Full Text | Free Full Text | Faculty Opinions Recommendation

68. F Rossi DJ, Bryder D, Seita J, et al.: Deficiencies in DNA damage repair limit the function of haematopoietic stem cells with age. Nature. 2007; 447(7145): $725-9$

PubMed Abstract | Publisher Full Text | Faculty Opinions Recommendation

69. Sudo K, Ema H, Morita $Y$, et al:: Age-associated characteristics of murine hematopoietic stem cells. J Exp Med. 2000; 192(9): 1273-80. PubMed Abstract | Publisher Full Text | Free Full Text

70. Ho YH, Mendez-Ferrer S: Microenvironmental contributions to hematopoietic stem cell aging. Haematologica. 2020; 105(1): 38-46. PubMed Abstract I Publisher Full Text Free FullText

71. F Mejia-Ramirez E, Florian MC: Understanding intrinsic hematopoietic stem 
cell aging. Haematologica. 2020; 105(1): 22-37.

PubMed Abstract | Publisher Full Text | Free Full Text |

Faculty Opinions Recommendation

72. Ergen AV, Boles NC, Goodell MA: Rantes/Ccl5 influences hematopoietic stem cell subtypes and causes myeloid skewing. Blood. 2012; 119(11): 2500-9. PubMed Abstract | Publisher Full Text | Free Full Text

73. Veith RC, Featherstone JA, Linares OA, et al:: Age differences in plasma norepinephrine kinetics in humans. J Gerontol. 1986; 41(3): 319-24. PubMed Abstract | Publisher Full Text

74. Ng AV, Callister R, Johnson DG, et al.: Age and gender influence muscle sympathetic nerve activity at rest in healthy humans. Hypertension. 1993; 21(4): 498-503.

PubMed Abstract | Publisher Full Text

75. Hart EC, Charkoudian N: Sympathetic neural regulation of blood pressure: influences of sex and aging. Physiology (Bethesda). 2014; 29(1): 8-15. PubMed Abstract | Publisher Full Text

76. F Zullo JM, Drake D, Aron L, et al.: Regulation of lifespan by neural excitation and REST. Nature. 2019; 574(7778): 359-64.

PubMed Abstract | Publisher Full Text | Free Full Text Faculty Opinions Recommendation

77. F Maryanovich M, Zahalka AH, Pierce $\mathrm{H}$, et al:: Adrenergic nerve degeneration in bone marrow drives aging of the hematopoietic stem cell niche. Nat Med. 2018; 24(6): 782-91.

PubMed Abstract | Publisher Full Text | Free Full Text

Faculty Opinions Recommendation

78. Busik JV, Tikhonenko M, Bhatwadekar A, et al:: Diabetic retinopathy is associated with bone marrow neuropathy and a depressed peripheral clock. J Exp Med. 2009; 206(13): 2897-906. PubMed Abstract | Publisher Full Text | Free Full Text

79. F Ferraro F, Lymperi S, Mendez-Ferrer S, et al:: Diabetes impairs hematopoietic stem cell mobilization by altering niche function. Sci Trans Med. 2011; 3(104): 104ra1.

PubMed Abstract | Publisher Full Text | Free Full Text |

Faculty Opinions Recommendation
80. Albiero M, Poncina N, Tjwa M, et al.: Diabetes causes bone marrow autonomic neuropathy and impairs stem cell mobilization via dysregulated p66Shc and Sirt1. Diabetes. 2014; 63(4): 1353-65.

PubMed Abstract Publisher Full Text

81. F Lucas D, Scheiermann C, Chow A, et al:: Chemotherapy-induced bone marrow nerve injury impairs hematopoietic regeneration. Nat Med. 2013; 19(6): 695-703.

PubMed Abstract | Publisher Full Text | Free Full Text | Faculty Opinions Recommendation

82. F Maestroni GJ, Togni M, Covacci V: Norepinephrine protects mice from acute lethal doses of carboplatin. Exp Hematol. 1997; 25(6): 491-4. PubMed Abstract | Faculty Opinions Recommendation

83. F Spiegel A, Shivtiel S, Kalinkovich A, et al:: Catecholaminergic neurotransmitters regulate migration and repopulation of immature human CD34+ cells through Wnt signaling. Nat Immunol. 2007; 8(10): 1123-31. PubMed Abstract | Publisher Full Text | Faculty Opinions Recommendation

84. Maestroni GJ, Conti A, Pedrinis E: Effect of adrenergic agents on hematopoiesis after syngeneic bone marrow transplantation in mice. Blood. 1992; 80(5): 1178-82 PubMed Abstract

85. Hanoun M, Zhang D, Mizoguchi T, et al: Acute myelogenous leukemia-induced sympathetic neuropathy promotes malignancy in an altered hematopoietic sympathetic neuropathy promotes malignancy in
stem cell niche. Cell Stem Cell. 2014; 15(3): $365-75$ stem cell niche. Cell Stem Cell. 2014; 15(3): 365-75.
PubMed Abstract | Publisher Full Text | Free Full Tex

86. F Arranz L, Sanchez-Aguilera A, Martin-Perez D, et al.: Neuropathy of haematopoietic stem cell niche is essential for myeloproliferative neoplasms. Nature. 2014; 512(7512): 78-81.

PubMed Abstract | Publisher Full Text | Faculty Opinions Recommendation

87. Drexler B, Passweg JR, Tzankov A, et al:: The sympathomimetic agonist mirabegron did not lower JAK2-V617F allele burden, but restored nestinpositive cells and reduced reticulin fibrosis in patients with myeloproliferative neoplasms: results of phase II study SAKK 33/14. Haematologica. 2019; 104(4): 710-6.

PubMed Abstract | Publisher Full Text | Free Full Text 


\section{Open Peer Review}

\section{Current Peer Review Status:}

\section{Editorial Note on the Review Process}

Faculty Reviews are review articles written by the prestigious Members of Faculty Opinions. The articles are commissioned and peer reviewed before publication to ensure that the final, published version is comprehensive and accessible. The reviewers who approved the final version are listed with their names and affiliations.

\section{The reviewers who approved this article are:}

\section{Version 1}

\section{Satoshi Yamazaki}

Division of Stem Cell Biology, Center for Stem Cell Biology and Regenerative Medicine, The Institute of Medical Science, The University of Tokyo, Tokyo, Japan

Competing Interests: No competing interests were disclosed.

\section{Partha Dutta}

${ }^{1}$ Department of Medicine and Immunology, Vascular Medicine Institute, Pittsburgh, PA, USA

2 Division of Cardiology, Department of Medicine, University of Pittsburgh Medical Center, Pittsburgh, PA, USA

Competing Interests: No competing interests were disclosed.

\section{Toshio Suda}

${ }^{1}$ Cancer Science Institute, National University of Singapore, Singapore, Singapore

2 International Research Center for Medical Sciences, Kumamoto University, Kumamoto City, Japan Competing Interests: No competing interests were disclosed. 
The benefits of publishing with F1000Research:

- Your article is published within days, with no editorial bias

- You can publish traditional articles, null/negative results, case reports, data notes and more

- The peer review process is transparent and collaborative

- Your article is indexed in PubMed after passing peer review

- Dedicated customer support at every stage

For pre-submission enquiries, contact research@f1000.com 